\title{
Pruning and Gibberellic Acid on the Growth and Yield Attributes of Onion (Allium cepa L.) var Agrifond Light Red
}

\author{
Omesh Thakur*, Vijay Kumar and Jitendra Singh \\ Department of Vegetable Science, Indira Gandhi Krishi Vishwavidyalaya, Raipur, \\ Chhattisgarh-492012, India \\ *Corresponding author
}

\section{A B S T R A C T}

Keywords

Onion, Pruning, Gibberellic acid,

Methods of

application, Growth,

Yield attributes

Article Info

Accepted:

10 December 2017

Available Online:

10 January 2018
A Field trial was carried out at Horticulture Farm of Indira Gandhi Krishi Vishwavidyalaya, Raipur, to assess the effect of pruning, Gibberellic acid and methods of application on growth and yield components were carried out on onion. Out of 19 treatment combinations comprised of three level of pruning, six levels of GA at different concentration and its methods of application viz., pruning (leaf pruning, root pruning, leaf and root pruning), GA (50, 100, $150 \mathrm{ppm}$ and method viz., root dip, foliar spray). The growth and yield attributing character were significantly differed due to different level of pruning and Gibberellic acid. The interaction effect of Leaf pruning along with GA 150 ppm as foliar spray was effective in maximum plant height, number of leaves per plant, weight of bulb, dry weight of bulb, yield ( $\mathrm{kg} / \mathrm{plot}$ ) while the minimum plant height, number of leaves per plant, weight of bulb, dry weight of bulb, yield (kg/plot) from control i.e. without leaf and root pruning and no GA control treatment.

\section{Introduction}

Onion (Allium cepa L.) is one of the oldest bulb crops, known to mankind and consumed worldwide. It is one of the most important commercial vegetable crops grown in India and believed to be originated in Central Asia. It is valued for its distinct pungent flavour and is an essential ingredient for the cuisine of many regions. Onion is the queen of the kitchen (Selvaraj, 1976). The onion is preferred mainly because of its green leaves, immature and mature bulbs are either eaten raw or cooked as a vegetable. Mild flavoured or colourful bulbs are often chosen for salads.
The bulbs are used in soups, sauces, condiments, spice, in medicine, seasoning of many foods and for the preparation of value added edible products like powder, flakes and salts. A distinct characteristic of onion is its alliaceous odour, which accounts for their use as food. The pungency in onion is due to a volatile compound known as Allyl-propyl disulphide. Onion has many uses as folk medicine and recent reports suggests that onion plays an important role in preventing heart diseases and other ailments (Augusti, 1990). According to Watt and Merill (1950), onion contains 11 amino acids. One hundred $g$ of raw onion bulb contains about $501 \mu \mathrm{g}$ 
vitamin 'A', $0.03 \mathrm{mg}$ of thiamine, $0.04 \mathrm{mg}$ of riboflavin, $0.02 \mathrm{mg}$ of niacin and $9 \mathrm{mg}$ of ascorbic acid and rest are the carbohydrates which make up the dry matter of the bulb.

$\mathrm{GA}_{3}$ is one of the important growth stimulating substances which promote cell elongation and cell division thus help in the growth and development of many plants. However, the improvement in the yield and quality of the crops mainly depends on the concentration of plant growth regulator and time of application (Singh, 1995).

Pruning is done mainly for balancing and influencing the nutrients and hormones. As a result of pruning the existing plant face less competition for nutrients and hormones. More nutrients and hormones are transported to the plant and they produce bigger, heavier and healthy bulb and seeds. Pruning associated with proper age of seedling is an important factor for successful onion production.

Therefore, the present investigation was carried out to study the effect of seedling pruning and Gibberellic acid $\left(\mathrm{GA}_{3}\right)$ and its application method on growth and yield of onion cv. Agrifond Light Red in Chhattisgarh Plains.

\section{Materials and Methods}

The field experiment was conducted in Indira Gandhi Krishi Vishwavidyalaya, Raipur (C.G.) to find out the effect of seedling pruning and Gibberellic Acid $\left(\mathrm{GA}_{3}\right)$ and its application method on growth and yield of onion cv Agrifond Light Red. The onion variety Agrifond Light Red was used in the experiment. It was a high yielding, grown in Rabi season. The experiment was laid out in factorial Randomize Block Design (RBD), with three replications. The treatments included: three levels of pruning (Root pruning (reducing the roots to $1.25 \mathrm{~cm}$ ), leaf pruning (reducing the leaves to $7 \mathrm{~cm}$ ), leaf and root pruning (reducing the leaves to $7 \mathrm{~cm}$ and roots to $1.25 \mathrm{~cm}$ ) and 6 levels of $\mathrm{GA}_{3}$ and its application method (50, 100, $150 \mathrm{ppm}$ as root dip and foliar spray) along with control. For root dipping treatments, seedlings were dipped for overnight hours before transplanting. Spraying with $\mathrm{GA}_{3}$ was done 30 days after transplanting.

\section{Preparation and application of GA3}

50 ppm solution of $\mathrm{GA}_{3}$ was prepared by dissolving $50 \mathrm{mg}$ of it with distilled water. Then distilled water was added to make the volume 1 litre $50 \mathrm{ppm}$ solution. In similar way $100 \mathrm{ppm}$ and $150 \mathrm{ppm}$ concentration were made. Five plants were selected at random and uprooted carefully at the time of collecting data of root from each plot. The data in respect of growth and yield components were statistically analyzed to find out the significance of the experimental results. The means of all the treatments were calculated and the analysis of variance for each of the characters. Data collection the data on the growth and yield characters viz., Plant height, Number of leaves, bulb diameter, bulb weight, bulb yield as influenced by pruning and GA and its application methods are presented in Table 1. Each of the parameters was measured as indicated below:

\section{Plant height (cm)}

Five randomly selected plants from each plot were tagged for recording observations. Plant heights from ground level up to the top of the tallest leaf were measured and the average height per plant was calculated.

\section{Number of leaves per plant}

Total number of green leaves of five randomly selected plants in each treatment was counted and the average was calculated. 


\section{Bulb diameter (cm)}

Diameters of five randomly selected bulb of the middle part were recorded by Vernier Caliper and average of them was expressed in centimeter $(\mathrm{cm})$.

\section{Average bulb weight (g)}

Weight of ten bulbs from randomly selected plants was recorded by weighing balance and average was calculated.

\section{Bulb fresh weight $(\mathrm{Kg} / \mathrm{plot})$}

The crop was dug out at as per maturity under different treatments. The foliage was removed and fresh weight of bulbs was recorded in each plot under all the treatments.

Statistical analysis was done for all parameters by adopting the procedures of Gomez and Gomez (1984).

\section{Results and Discussion}

\section{Effects of pruning}

Pruning showed influence on all the vegetative and quality parameters of onion cv. Agrifond light Red. The maximum plant height (48.36 $\mathrm{cm}$ ) and number of leaves per plant (8.95) were recorded from leaf pruning respectively, while the minimum plant height $(39.02 \mathrm{~cm})$ and number of leaves per plant (7.71) were obtained from the leaf and root pruning (Table 1). Maximum bulb diameter $(6.36 \mathrm{~cm})$, Wt. of bulb $(58.23 \mathrm{~g})$, yield of bulb $(12.32 \mathrm{~kg} / \mathrm{plot})$ was recorded at leaf pruning followed by root pruning. Minimum bulb diameter $(5.00 \mathrm{~cm})$, Wt. of bulb (71.06 g), yield of bulb (9.61 $\mathrm{kg} / \mathrm{plot}$ ) was obtained from the leaf and root pruning (Table 1 and 2). The plant height and number of leaves per plant gradually increased up to maximum vegetative growth stage the results indicated that maximum number of leaves was produced in the onion with pruning practices. It may be due to the pruning enhance to producing more number of leaves.

\section{Effects of $\mathrm{GA}_{3}$ and its application methods}

The result demonstrated that $\mathrm{GA}_{3}$ had significant influence on the growth and yield parameters of onion. The maximum plant height $(46.02 \mathrm{~cm})$ and number of leaves per plant (8.67) were recorded from GA $150 \mathrm{ppm}$ as foliar spray respectively, while the minimum plant height $(39.02 \mathrm{~cm})$ and number of leaves per plant (8.13) were obtained from GA $50 \mathrm{ppm}$ as root dipping methods (Table $1)$.

The increased plant height and number of leaves might be due to repid increase in cell division and cell elongation in the meristemic region. These results are in close confirmity with those of Gupta and Gupta (2000) and Rai et al., (2006), (Nibhavanti et al., 2006) observed that GA increased the number of leaves per plant.

Maximum bulb diameter $(6.09 \mathrm{~cm})$, Wt. of bulb (77.62 g), yield of bulb (11.86 kg/plot) was recorded from GA $150 \mathrm{ppm}$ as foliar spray and this trend was followed by similar treatment applied at lower doses i.e. 100 and $50 \mathrm{ppm}$.

Minimum bulb diameter $(5.25 \mathrm{~cm})$, Wt. of bulb $(64.57 \mathrm{~g})$, yield of bulb $(10.38 \mathrm{~kg} / \mathrm{plot})$, were obtained from GA $50 \mathrm{ppm}$ as root dipping (Table 1). Takagi and Aoba (1976) reported that foliar spray of higher concentrations of $\mathrm{GA}_{3}$ caused reduction in bulb growth of garlic. The present bulb diameter due to leaf pruning in the present study could be due to the fact of that pruning might have oriented to the plant to their light supply and enable the plant to produce more food materials and store which ultimately results the increased bulb diameter. 
Table.1 Effect of pruning, Gibberellic acid and its method of application on growth and yield characters of onion

\begin{tabular}{|c|c|c|c|c|c|}
\hline Treatment & $\begin{array}{l}\text { Plant height } \\
\text { (cm) }\end{array}$ & $\begin{array}{c}\text { Number of } \\
\text { leaves per plant }\end{array}$ & $\begin{array}{l}\text { Diameter of } \\
\text { bulb (g) }\end{array}$ & $\begin{array}{l}\text { Wt. of bulb } \\
\text { (g) }\end{array}$ & $\begin{array}{l}\text { Yield of bulb } \\
\text { (kg/plot) }\end{array}$ \\
\hline \multicolumn{6}{|l|}{ Pruning method } \\
\hline P1(RP) & 41.26 & 8.36 & 5.60 & 70.59 & 11.01 \\
\hline $\mathbf{P 2}$ (LP) & 48.36 & 8.95 & 6.36 & 82.94 & 12.32 \\
\hline $\mathbf{P 3}(\mathbf{R P}+\mathrm{LP})$ & 39.02 & 7.71 & 5.00 & 58.23 & 9.61 \\
\hline SEm \pm & 0.63 & 0.07 & 0.13 & 1.21 & 0.27 \\
\hline CD (5\%) & 1.30 & 0.14 & 0.27 & 2.49 & 0.55 \\
\hline \multicolumn{6}{|c|}{$\mathrm{GA}_{3}$ and its application method } \\
\hline G1 (50 ppm as RD) & 41.18 & 8.13 & 5.25 & 64.57 & 10.38 \\
\hline G2 (50 ppm as RD) & 43.54 & 8.46 & 5.75 & 72.12 & 10.92 \\
\hline G3 (100 ppm as RD) & 41.40 & 8.16 & 5.27 & 64.86 & 10.56 \\
\hline G4 (100 ppm as FS) & 44.19 & 8.64 & 6.07 & 77.54 & 11.54 \\
\hline G5 (150 ppm as RD) & 40.93 & 8.42 & 5.50 & 66.82 & 10.62 \\
\hline G6 (150 ppm as FS) & 46.02 & 8.67 & 6.09 & 77.62 & 11.86 \\
\hline SEm \pm & 0.82 & 0.10 & 0.18 & 1.56 & 0.35 \\
\hline CD (5\%) & 1.68 & 0.21 & 0.38 & 3.21 & 0.71 \\
\hline
\end{tabular}

Table.2 Interaction effect of pruning, Gibberellic acid and its method of application on growth and yield characters of onion

\begin{tabular}{|c|c|c|c|c|c|}
\hline Treatment & $\begin{array}{l}\text { Plant height } \\
\text { (cm) }\end{array}$ & $\begin{array}{c}\text { Number of leaves } \\
\text { per plant }\end{array}$ & $\begin{array}{l}\text { Diameter of } \\
\text { bulb }(\mathrm{g})\end{array}$ & Wt. of bulb (g) & $\begin{array}{l}\text { Yield of bulb } \\
\text { (kg/plot) }\end{array}$ \\
\hline P1G1 & 39.34 & 8.53 & 5.20 & 62.77 & 10.10 \\
\hline $\mathbf{P}_{1} \mathbf{G}_{2}$ & 42.60 & 8.37 & 5.83 & 74.22 & 11.52 \\
\hline$P_{1} G_{3}$ & 42.24 & 8.37 & 5.43 & 68.28 & 11.09 \\
\hline$P_{1} G_{4}$ & 41.68 & 8.63 & 6.07 & 81.88 & 11.88 \\
\hline$P_{1} G_{5}$ & 37.33 & 7.83 & 5.07 & 58.80 & 9.80 \\
\hline$P_{1} G_{6}$ & 44.36 & 8.40 & 5.97 & 77.58 & 11.68 \\
\hline P2G1 & 45.53 & 8.30 & 5.42 & 68.05 & 10.85 \\
\hline P2G2 & 50.88 & 9.37 & 6.58 & 87.34 & 12.90 \\
\hline P2G3 & 36.40 & 8.37 & 5.43 & 68.95 & 11.13 \\
\hline P2G4 & 53.65 & 9.57 & 7.15 & 94.02 & 12.95 \\
\hline P2G5 & 48.22 & 8.40 & 6.43 & 84.94 & 12.27 \\
\hline P2G6 & 55.46 & 9.70 & 7.17 & 94.35 & 13.84 \\
\hline P3G1 & 38.67 & 7.57 & 5.13 & 62.89 & 10.20 \\
\hline P3G2 & 45.58 & 7.62 & 4.84 & 54.79 & 8.35 \\
\hline P3G3 & 37.15 & 7.73 & 4.96 & 57.33 & 9.45 \\
\hline P3G4 & 41.02 & 8.27 & 5.37 & 64.12 & 10.74 \\
\hline P3G5 & 36.78 & 7.72 & 4.98 & 56.73 & 9.79 \\
\hline P3G6 & 38.25 & 7.90 & 5.13 & 60.92 & 10.07 \\
\hline P0G0 & 35.13 & 7.50 & 3.67 & 44.33 & 6.75 \\
\hline $\mathrm{SE} \pm$ & 1.42 & 0.17 & 0.23 & 2.71 & 0.60 \\
\hline CD (5\%) & 2.91 & 0.36 & 0.47 & 5.56 & 1.24 \\
\hline \multicolumn{6}{|l|}{ Control vs rest } \\
\hline $\mathrm{SE} \pm$ & 1.03 & 0.12 & 0.32 & 1.97 & 0.43 \\
\hline CD (5\%) & 2.11 & 0.26 & 0.66 & 4.04 & 0.89 \\
\hline
\end{tabular}


The findings of the studies are in contrast with the result of Nahar (2007) who stated that maximum bulb diameter from leaf along with root pruning under the agro climatic condition of Bangladesh in the experiment with pruning and irrigation treatment in onion var. N-53.

Yield is an important character which is responsible for the commercial feasibility of a crop variety and is also one of the most essential traits attaining highest consideration in a research programme. The present studies are in congruent with Memane et al., (2008) who reported that increased vegetative and bulb growth observed in large sized clove due to more reserve food materials might had helped in increasing the overall yield of garlic. Singh et al., (1995) have reported that application of growth regulators increase the accumulation of food materials and bulb yield in onion. It can be concluded the GA was found most effective in enhancing the bulb yield.

Interaction effects showed a significant influenced on the growth and yield of onion. The maximum plant height $(55.46 \mathrm{~cm})$ and number of leaves per plant (9.70) were recorded from leaf pruning respectively, while the minimum plant height $(35.13 \mathrm{~cm})$ and number of leaves per plant (7.70) were obtained from the control plots (Table 2). The maximum bulb diameter $(7.17 \mathrm{~cm})$, Wt. of bulb (94.35 g), yield of bulb (13.84 kg/plot) was recorded from GA $150 \mathrm{ppm}$ as foliar spray leaf pruning followed by GA 100 ppm as foliar spray. Minimum bulb diameter (3.67 $\mathrm{cm})$, Wt. of bulb (44.33g), yield of bulb $(6.75$ $\mathrm{kg} / \mathrm{plot}$ ) was obtained from control (Table 2).

Most of the treatment combination significantly increased the growth and yield over control treatment. Patel et al., (2010) reported increased bulb diameter with Gibberellic acid application in onion. The results are with close agreement with Tyagi and Yadav (2007).

On the basis of experiment, it is concluded that, pruning and gibberellic acid had significant influence on growth and yield of onion. Among the different treatments of pruning and gibberellic acid, the plants treated with the application of GA3 @ 150 ppm showed an increased Plant height, number of leaves, and Diameter of bulb, Yield per plot (kg). Leaf Pruning increased the sizes of onion which resulted in higher of fruit yield of the onion. However, better and stable fruit yield of onion could be obtained with the practice of pruning in combination of gibberellic acid. From the results of this study, it could be concluded that pruning treatment produced best results in terms of growth and bulb fresh yield of onion and therefore, could be recommended as suitable crop management practice for increased yield of onion.

\section{References}

Augusti, K.T., 1990. Therapeutic and medicinal values of onion and garlic. In Onion and Allied Crops. Ed. Brewster, J.L. and Rabinowith, H.D., Baco Ratani, Florida, CRC Press, 3: 93-108.

Barkar, A. J. and Prasad, R. N. 1990. Effect of gibberellic acid and NAA on growth and quality of onion. Progressive Horticulture, 22 (1-4): 60-62.

Deka, B.C. and Shadeque, A. 1993. Interaction effect of spacing, mulching and clove size on growth and yield of garlic (Allium sativum L). South Indian Horticulture 41(3): 159-161.

Gomez, K. A. and Gomez, A. A. 1984. Statistical procedures for agricultural research. John Willey and Sons, New York

Gupta, P.K. and Gupta, A.K. 2000. Efficacy of plant growth regulators (IAA and 
NAA) and micronutrient mixture on growth, flowering, fruiting and shelf life of tomato (Solanum lycopersicon Mill.). Current Agriculture 32 (1\&2):83-86.

Memane, P.G., Tomar, R.S., Kakade, D.K., Kulkarni, G.U. and Chovatia, R.S. 2008. Effect of clove weight and plant growth regulators on growth and yield of garlic (Allium sativum Linn) cv. GG 3. The Asian Journal of Horticulture 3(1): 82-86.

Nibhavanti, B., Bhalekar, M.N., Gupta, N.S., Anja1i D. Effect of growth regulators on growth and yield of tomato in summer. Maharastra J Agric 2006; 31(1):64- 65.

Rai, N., Yadav, D.S., Patel K.K., Yadav,
R.K., Asati, B.S. and Chaubey, T.2006. Effect of plant growth regulators on growth, yield and quality of tomato, (Solanum lycopersicon Mill.) grown under mid hill of Meghalaya. Vegetable Science; 33(2):180-182.

Selvaraj, S., 1976. Onion: Queen of the kitchen. Kisan World, 3(12): 32-34.

Takagi, H. and. Aova, T. 1976. Studies on the bulb formation in garlic plants. $J$. Yamayata Agric. Forestry Soci., 33: 3950.

Tomar, I.S. and Ramgiry, S.R. 1997. Effect of growth regulator on yield and yield attributes in tomato Lyropersicon esculentum Mill. Adv PI Sci, 10(2):2931.

\section{How to cite this article:}

Omesh Thakur, Vijay Kumar and Jitendra Singh. 2018. Pruning and Gibberellic Acid on the Growth and Yield Attributes of Onion (Allium cepa L.) var Agrifond Light Red. Int.J.Curr.Microbiol.App.Sci. 7(01): 976-981. doi: https://doi.org/10.20546/ijcmas.2018.701.117 